\title{
Woman's Self-Realisation in the Poetry of Thomas Hardy
}

\author{
Maha Qahtan Sulaiman ${ }^{1}$ \\ ${ }^{1}$ English Department, College of Education for Women, University of Baghdad, Baghdad, Iraq \\ Correspondence: Maha Qahtan Sulaiman, English Department, College of Education for Women, University of \\ Baghdad.
}

\author{
Received: October 12, 2018 Accepted: November 7, 2018 Online Published: November 28, 2018 \\ doi:10.5539/ells.v8n4p58 URL: https://doi.org/10.5539/ells.v8n4p58
}

\begin{abstract}
A comprehensive investigation of Thomas Hardy's poetry reveals the doctrines of Existentialism which were new and not common during the 19th century. Hardy's poetry, combining both Modern and Victorian elements, proclaims the emancipation from the fetters of money and religious oriented orthodox heritage. Hardy believes that the struggle for existence is the canon of life and, therefore, human cooperation is a necessity to man's wellbeing. Though Hardy's religious beliefs declined, mainly the concepts of divine intervention, absolution, and afterlife, he did not relinquish his faith in the moral principles of the Christian Church. This is expressed in his poetry through an intense desire to elevate man's status in the world, to secure the transition of man's existence from insignificance to accomplishment and excellence. The present study examines Hardy's poetry in the light of the existentialists' belief that man can achieve supremacy by being conscious of one's limitations, ethical responsibilities, and duties. The focus of the study is on female characters in Hardy's poetry, whose elevated consciousness and self-realisation present an ethical model that can assist the development of humanity and improve the world.
\end{abstract}

Keywords: existentialism, individuality, self-realisation, transcendence, woman

\section{Literature Review}

The existentialist thinkers have always underpinned the significance of a subjective and authentic attitude of life. They emphasise individual self-realisation through responsibility and freedom. Karl Jaspers (1951) explains existentialism as "the way of thought by means of which man seeks to become himself" (p. 159). Existentialists believe that human life should manifest transcendence, and that man needs to realise what he should become and has the ability to achieve it. Atheist Existentialism declares that man's existence precedes his essence and that "every truth and every action implies a human subjectivity" (Sartre, 1955, p. 12). According to Sartre, "people exist, confront themselves, emerge in the world, and define themselves afterward. First, we simply are, and then we are simply that which we make of ourselves" (Stumpf and Fieser, 2008, p.434). Therefore, man needs to make correct decisions and be in accord with his conscience, community, and biological habitat. Mallikarjun Patil (1999) mentions that Thomas Hardy was acquainted with no existentialist philosopher other than Nietzsche (p. 33). Hardy praises Nietzsche in his Literary Notes: "Nietzsche's philosophy reaffirmed with emphasis and faith the worth of life and the splendour of human destiny", Hardy further asserts, "Nietzsche stands for the affirmation of life" (Bjork, 1985, pp. 450-51). Nevertheless, Patil (1999) writes that Hardy's "wide observation and experience of life enabled him to know the characteristic features of the philosophy of existence. In this regard, he may be considered an existentialist thinker" (p. 33). Hardy's ideas, which were basically the reflection of his very natural self and deep thinking, were considered radical to the Victorians. Like most existentialist thinkers, Hardy believes that there is no God. Instead, he embraces the notion that there exists 'the Unconscious Will of the Universe'; a mysterious force that invariably hampers man's improvement and growth. Relevantly, Geoffrey Harvey (2003) maintains that 'Hardy also assimilated something of his parents' fatalism. From his father it was a straightforward acceptance of what life offered, but from his mother came a strong vein of pessimism" (p. 6). As regards Hardy's earlier religious beliefs, Michael Millgate (1985) writes the following:

Though not insincere-because never consciously examined-his early adherence to Anglican principles was largely automatic, taken for granted upon the basis of family and local example. His fundamental beliefs, meanwhile, appear to have differed little from the instinctive, inherited fatalism of a Tess Durbeyfield-or of Jemima Hardy-and, as sophisticated by exposure to Marcus Aurelius, they found little difficulty in accommodating themselves to the prevailing pessimism of the post-Darwinian intellectual world into which he 
emerged in early manhood. The erosion of Hardy's religious convictions was thus a gradual process rather than the consequence of a single moment of crisis, and he was never to lose entirely his imaginative adherence to the Church, his love of its music and its services, and his belief in its civilizing and socializing functions. (p. 91)

Hardy's lack of formal education, Millgate (1985) claims, made it less difficult for him to range "ideas newly derived from Darwin and Huxley alongside the necessitarian views already instilled in him by both the peasant fatalism of his upbringing and the tragic patterns of Greek dramatists" (p. 132). Hardy's approach to life was more emotional than intellectual, and essentially based on his gut feelings and instincts. Finally, in a letter written to John Morley, Hardy expresses his hope for the regeneration of the structure of the Church of England:

I have sometimes had a dream that the church, instead of being disendowed, could be made to modulate by degrees (say as the present incumbents die out) into an undogmatic, non-theological establishment for the promotion of that virtuous living on which all honest men are agreed-leaving to voluntary bodies the organization of whatever societies they may think best for teaching their various forms of doctrinal religion. (Millgate, 1985, p. 247)

Hardy's engagement with the scientific theories and philosophical trends of his age was an attempt to fill the void caused by losing his faith. Thinking of himself as a meliorist, Hardy is of the opinion that man needs to grant moral value to a chaotic world ruled by fate. In an interview, Hardy explains his viewpoint to William Archer: "My practical philosophy is distinctly meliorist. What are my books but one plea against 'man's inhumanity to man' - to woman - and to the lower animals?" (Gibson, 1999, p. 70). Thus, Hardy attempts to compromise between pessimism and optimism, which reflects his positive vision of the future. In his preface to Poems of the Past and the Present, Hardy (1983) writes: "The road to a true philosophy of life seems to lie in humbly recording diverse readings of its phenomena as they are forced upon us by chance and change" (p. 84). Hardy, a committed humanist, had a special affinity for struggling human beings and labourers. He perceives man's life as a prolonged hard work in an unsympathetic society. In his Literary Notes, Hardy quotes Victor Hugo:

He insists on the smallness of the personal element in life, the powerlessness of the human will in the face of inanimate forces such as superstition, society, or nature; dogmas, codes and things; religion, prejudice, or the elements ... man is not supreme, but a powerless unit in a crowd. Hugo's theme is the predestined fate of human existence the struggle between man and destiny; he insists upon the compulsion of circumstances, the tragic force that overrides the human will. (Bjork, 1985, p. 169)

Most of Hardy's protagonists have failed to assert their will power and achieve transcendence in a hostile or indifferent universe. The present study, however, investigates some of Hardy's poems, where Woman struggles for existence against inanimate forces; and manifests an authentic life and heroism through nobility, commitment, and resistance amidst adversity and hardship. The study examines women whose activities and choices reflect their willing for self-realisation through conscious existence.

Hardy was greatly influenced by John Stuart Mill, a prominent philosopher and economist. He was "perhaps the most enlightened and far-seeing thinker of his generation", significantly Mill "campaigned for women's rights" (Williams, 1976, p. 83). Hardy was especially influenced by Mill's The Subjection of Women (1970), where the latter writes; "human beings are no longer born to their place in life, and chained down by an inexorable bond to the place they are born to, but free to employ their faculties, and such favorable chances as offer to achieve the lot which may appear to them most desirable" (pp. 17-18). This notion of human liberty of social and economic oppressions appealed to the class-conscious Hardy. Interestingly, Hardy, who called his mother a 'progressive', "never underestimated woman's capabilities in business or society" (Maynard, 1991, p. 115). In this regard, Hardy's oeuvre portrays heroines who repeatedly defied social tyranny and suffered accordingly for being misunderstood by their community. This study investigates female figures in Hardy's poetry who assert their individuality and independence. They are revolutionaries who repudiate the obstructions and oppressive tenets of society. Hardy's intension is to demonstrate that woman should cherish the privilege of living according to her inner calling in life.

In Literary Notes, Hardy refers to the vital part of woman in man's life: "Without women, the beginning of our life would be helpless; the middle, devoid of pleasure; and the end, of consolation" (Bjork, 1985, p. 30). Hardy's "Conjecture" reasserts the crucial role of woman in his life:

If there were in my Kalendar

No Emma, Florence, Mary,

What would be my existence now - 
A hermit's? - wanderer's weary? -

How should I live, and how

Near would be death, or far? (Hardy, 1983, p. 477)

Existentialist thinkers, like Jaspers and Sartre, highlight the supremacy of women as guardians of and responsible for a happy domestic life (Patil, 1999, p. 58). Hardy could not resist his attraction to powerful, intellectual, and beautiful women; all being traits that characterised women whom he had intimate relationships with. His versatile interests and power insight qualified him to write, with love and sympathy, poetry about women from different social backgrounds, in diverse circumstances and predicaments.

\section{Discussion}

Hardy's "The Dance at the Phoenix" reveals that true love can stimulate spiritual rebirth and ensure secureness. The poem presents Jenny who was not pure before meeting her husband to be. After marriage, however, she cherished a peaceful life of intimacy, trust, and honour. Conjugal love developed into a life of domestic happiness and harmony for her. Near the end of Jenny's life, she turned towards her husband and then:

She kissed him long, as when, just wooed,

She chose his domicile.

She felt she would give more than life

To be the single-hearted wife ... (Hardy, 1983, p. 47)

The couple's genuine relationship is pivotal to their existence and contentment; it provides them with self-realisation through an ideal and stable emotional life. This poem differs from many of Hardy's poems that present failed relationships, suffering from a breach of trust or sexual incompatibility. Hardy was attempting through these poems to show that happiness in marriage could be attained through mutual tenderness, loyalty, and respect between partners.

An aged teacher's memories are the topic of "In a Eweleaze near Weatherbury", where a woman recalls her dance "with one who kindled gaily / Love's fitful ecstasies" (Hardy, 1983, p. 70). Her memories evoke the sense of her feminine charms and passions. The woman's passions have not declined, and she continues to cherish her physical beauty more than her spiritual goodness:

Still, I'd go the world with Beauty,

I would laugh with her and sing,

I would shun divinest duty

To resume her worshipping. (Hardy, 1983, p. 71)

But the woman would soon realise her futile attempt to celebrate physical beauty and sexual passions in old age:

But she'd scorn my brave endeavour,

She would not blame the breeze

By murmuring 'Thine for ever!'

As she did upon this leaze. (Hardy, 1983, P. 71)

The woman is quite aware that her physical beauty had not survived the ravage of time. Her approach to life, nevertheless, was assertive and realistic.

Feminine smoothness and supremacy are presented in "The Milkmaid" through the milkmaid's peaceful relationship with Nature. The undertone of the maid's suffering and delight is evident throughout the poem. However, Hardy perceives the young maid as part of her sublime natural surroundings;

The flowery river-ooze

Upheaves and falls; the milk purrs in the pail;

Few pilgrims but would choose

The peace of such a life in such a vale.

The maid breathes words - to vent,

It seems, her sense of nature's scenery,

Of whose life, sentiment, 
And essence, very part itself is she ... (Hardy, 1983, p. 157)

Regarding the inhabitants of rural areas, and relevant to the lines quoted above, Hardy mentions the following in an interview with Archer:

Have you ever noticed the different relation to nature of the town child and the country child? The town-bread boy will often appreciate nature more than the country boy, but he does not know it in the same sense. He will rush to pick a flower which the country boy does not seem to notice. But it is part of the country boy's life. It grows in his soul - he does not want it in his buttonhole. (Gibson, 1999, p. 67)

The maid is content with her life through 'stoic-resignation' and readiness to live with Nature. "In all his books, without any effort, Mr. Hardy brings in nature as a personality, now aiding, now at war with man, now subdued, now triumphant, but always as living and in relation to human life. There is something of the relic of old paganism in his way of viewing her" (Cox, 1970, p. 86). The milkmaid, ultimately, "bends a glance of pain, / And, at a moment, lets escape a tear" (Hardy, 1983, p. 157). The lines reveal Hardy's final rejection of Wordsworth's vision of nature as a moral guide, an attitude which he mainly developed under the influence of Mill. He associates Nature with the Immanent Will and Fate. The poem, however, presents a woman whose relation with Nature is indispensable for a redemptive and fruitful life. The milkmaid incarnates Hardy's concept of the ideal womanhood.

The widow in "Her Late Husband" ignores the community's traditions of burying husband and wife alongside each other. She asks the sexton to bury her husband beside the woman whom he loved, and "after whose death he seemed to ail, / Though none considered why" (Hardy, 1983, p. 165). Her noble spirit is revealed as she explains to the sexton that, by burying her husband beside his real love, the angels would recognise the two loves as husband and wife:

Here is a man who takes his rest

Beside his very love,

Beside the one who was his wife

In our sight up above. (Hardy, 1983, p. 166)

The widow then asks the sexton that her own burial place be among her relatives and that her "maiden name" be inscribed on her tombstone:

And when I also claim a nook,

And your feet tread me in,

Bestow me in my maiden name,

Among my kith and kin,

That strangers gazing may not dream

I did a husband win. (Hardy, 1983, p. 166)

The widow chooses to be true to herself, admitting that real marriage is that of the souls and not mere physical union. She is a courageous, noble, and sensitive woman who would not hesitate to embrace the truth of her situation despite the pain of her injured pride and social embarrassment. Her choice comes from strength and therefore it elevates the quality of her life.

"The Elopement" presents a stubborn woman, single-minded in her desire to elope with her lover despite the possible consequences. But, Hardy writes; "in time convention won her, as it wins all women at last, / And now she is rich and respectable, and time has buried the past" (Hardy, 1983, p. 378). The woman escapes with her lover from an unfulfilled life; she transcends the chains imposed upon her by society. This woman, being an individualist, is not self-absorbed or worried about pleasing her lust. On the contrary, she achieves self-realisation and enhances her life by creating her own values and committing herself to them, and by reconciling her inner conscience with her outer deeds. Hardy frequently presents women who disobey the rules of their community because "they find it does not answer to their needs. It seems to impose a circumscribed life of petty concerns which offers no fulfilment to their large souls" (Miller, 1970, p. 115). In respect to this poem, Hardy was always haunted by irrevocable choices in life, the road untaken; these worries are reflected in his novels and poems. Yet unlike the famous female protagonists of his novels, the woman of the poem succeeds in seizing the opportunity to materialise her dreams. She says yes to life and asserts through her will the type of existence she aspires for. 
The feminine spirit dominates Hardy's "Old Furniture", where the speaker sits "amid relics of householdry / That date from the days of [... his] mother's mother" (Hardy, 1983, p. 485). The speaker imagines the hands of his relatives "that owned each shiny familiar thing / In play on its knobs and indentations, / And with its ancient fashioning / Still dallying" (Hardy, 1983, p. 485). He senses the strong presence of his deceased relatives haunting the place. "We live in the present, but we are conscious creatures, and we are weighed down by memories, which are all partial losses, and which one day become total losses" (Gunn, 1979, p. 226). The speaker can vividly recall the hands of his mother and grandmother, but then:

Hands behind hands, growing paler and paler,

As in a mirror a candle-flame

Shows images of itself, each frailer

As it receded, though the eye may frame

Its shape the same.

On the clock's dull dial a foggy finger,

Moving to set the minutes right

With tentative touches that lift and linger

In the wont of a moth on a summer night,

Creeps to my sight. (Hardy, 1983, p. 486)

The speaker's remembrance of family members at work on their furniture is "a resurrection that offers a means of spiritual renewal" (Harvey, 2003, p. 122). Woman does not appear in flesh and blood in this poem, yet she is presented as a concept of the common and simple activities that are associated with human existence.

Hardy's "During Wind and Rain" is another poem about remembrance that is associated with a female figure. It concerns Emma's, the poet's first wife, family home. Woman is depicted as part of domestic happiness and loving-kindness. Hardy draws fleeting images of a big family in perfect harmony:

They sing their dearest songs -

$\mathrm{He}$, she, all of them - yea,

Treble and tenor bass,

And one to play ... (Hardy, 1983, p. 495)

The family members "clear the creeping moss - / Elders and juniors" (Hardy, 1983, p. 495), preparing the garden for out of doors breakfast: "They are blithely breakfasting all - / Men and maidens - yea, / Under the summer tree" (Hardy, 1983, p. 495). Their activity stands for affirming human will and culture within the natural landscape. The refrain, "Ah, no; the years O!", that concludes each stanza of the poem alternatively with "Ah, no; the years, the years;" reminds us of time and human mortality. The "rotten rose [that ] is ript from the wall" (Hardy, 1983, p. 495) is a symbol of sickness, decay and death; contributing to the elegiac tone of time past and evoked memories. In the final stanza, the family is moving house and the vivid scenes of the past "are blotted out one by one until, with the slow-down of the inexorably erosive rain on the inscriptions, the poem closes with the thought of oblivion" (Pinion, 1977, p. 186):

They change to a high new house,

$\mathrm{He}$, She, all of them - aye,

Clocks and carpets and chairs

On the lawn all day,

And brightest things that are theirs....

Ah, no; the years, the years;

Down their carved names the rain-drop ploughs. (Hardy, 1983, p. 496)

Though the family is moving to probably a more commodious dwelling, the language is evocative, lucid and threatening. Harvey (2003) is of the opinion that "the awareness of a terrifying nullity at the heart of things, shared by the inhabitants of the poem, and endorsed by the refrain, is nevertheless transcended by their will to pursue actions that celebrate the human values of love, fellowship, adventure and gaiety" (p. 123). Past memories are associated with concepts of friendship, happiness and human determination. The poem presents 
men and women who stand for human capacity of abundance and fecundity, and who affirm life despite its grief and wickedness.

The image of woman as part of the realisation of life appears in the final stanza of "In Times of "The Breaking of Nations"'. The attitude which the poem conveys was formulated by Hardy in 1870, when he was occupied by the Franco-Prussian war while observing some agricultural activity that was taking place in a field in Cornwall. Yet the poem was not written till many years later, at the beginning of World War I in 1914, when Hardy recalled his old emotions at times of national conflicts (Lall, 2006, p. 110). Hardy holds the view that the basic interests of human beings will continue without change regardless of the mass destruction caused by war. In his interview with Archer he mentions that war "is doomed by the gradual growth of the introspective faculty in mankind - of their power of putting themselves in another's place, and taking a point of view that is not their own. [...] Not to-day, nor to-morrow, but in the fullness of time, war will come to an end, not for moral reasons, but because of its absurdity" (Gibson, 1999, pp 70-71). In the final stanza of the poem, an image of woman appears in confirmation of the continuity of life,

Yonder a maid and her wight

Come whispering by:

War's annals will cloud into night

Ere their story die. (Hardy, 1983, p. 543)

The image of the young woman with her lover, intimately engaged together, promises life and productivity that would outlast war chronicles and destruction. It runs parallel with an earlier image of a 'man harrowing clods' to keep the land fruitful. The European armed forces are ephemeral, unlike the permanence of the natural world and human race.

In "Last Look round St Martin's Fair", Hardy presents a fair gradually closing at sunset as some men drive their unsold animals "to the shades of the Great Forest whence they came" (Hardy, 1983, p. 765). The "brown monochrome' clothes of these men "indicate their affinity to the earth [...]. They live and work according to natural cycles, relatively unconscious, it is assumed, of humanity's metaphysical being" (Maynard, 1991, p. 165). Hardy contrasts these men with the figure of the woman at the nut-stall, who is associated with sports. She stands for the realisation of human's deepest capacities;

The woman in red, at the nut-stall with the gun,

Lights up, and still goes on:

She's redder in the flare-lamp than the sun

Showed it ere it was gone.

Her hands are black with loading all the day,

And yet she treats her labour as 'twere play,

Tosses her ear-rings, and talks ribaldry

To the young men around as natural gaiety,

And not a weary work she'd readily stay,

And never again nut-shooting see,

Though crying, 'Fire away!' (Hardy, 1983, p. 765)

The woman's red clothes are conspicuously dissimilar to the 'brown monochrome' garments of the other men in the fair. "By appearing 'redder' after sunset, she defies the natural cycle of day and night that dictates rest at darkness" (Maynard, 1991, p. 167). She stands for the gloriousness of humanity, treating 'her labour as 'twere play' and maintaining her vigorous spirit at the end of the day. She cries, presumably at the nut-shooters, 'Fire away', in resistance of the natural forces that dictate human activities. The woman of the poem distinguishes herself and asserts her individuality amid the complicated fabric of life which constitutes both man and nature, tightly knit together.

Hardy presents another self-determined woman in "Expectation and Experience". The woman of the poem gives an account of her attempt to get 'rid of melancholy' and enjoy her holiday. She decides to go to 'a good big fair', but then, at the fair: 
'it rained in torrents, drenching

Every horse, and sheep, and yeoman,

And my shoulders, face and hair;

And I found that I was the single woman

In the field - and looked quite odd there!

Everything was spirit-quenching:

I crept and stood in the lew of a wall

To think, and could not tell at all

What on earth made me plod there!' (Hardy, 1983, p. 847)

The woman's comic description of her failed attempt to have a cheerful time implies that actually she had cherished the difficulty of her experience, the trustless nature, and the awkwardness of being the only woman in the fair. Taking joy in difficulty and accepting failure liberated her from melancholy. The sense of humour, John Bayley (1978) writes, is "one of the ways in which consciousness made existence tolerable" (p. 77). The poem presents a woman with lucid sensitivity, and whose excellent sense of humour empowers her presence and self-confidence.

In "We Field-Women", a group of courageous women are 'trimming swedes' at Flintcomb-Ash. The poem illustrates their dignity and capacity to stand above pain. They have to work in the field even under the rain and endure being wet: "The wet washed through us - plash, plas, plash: / How it rained" (Hardy, 1983, p. 881). When they "crossed from Flintcomb-Ash / To the Great Barn for drawing reed" (Hardy, 1983, p. 881), the field women would have to continue their labour in the bitter cold and snowy conditions: "Flakes in each doorway and casement-sash: / How it snowed" (Hardy, 1983, p. 881). Yet Once they returned to their dairy work again, the field women cherished the delights of summer which is associated with love and cosmic happiness:

How it shone

When we went from Flintcomb-Ash

To start at dairywork once more

In the laughing meads, with cows three-score,

And pails, and songs, and love - too rash:

How it shone! (Hardy, 1983, p. 881)

The poem develops from the bleak and cruel conditions of the severe winter at Flintcomb-Ash and the Great Barn to the joys of sunshine and the merriments of flirting in the meadows. The field women have survived the violent and revengeful spirit of nature during winter to be rewarded by the resurrection of life and love in summer. The poem is a portrait of the women's great physical strength and unrelenting spirits that enabled them to proceed their journey through an equally determined and powerful landscape.

\section{Conclusion}

Hardy's poetry presents women who transcend towards courage and humanity, confirming the necessity of fellowship, kindness, and being actively involved in their social surroundings. Their subjectivity incarnates existentialists' notion of achieving supremacy by living authentically. Also important is that women in Hardy's poetry choose wisely and act appropriately. Their individuality and goodness become an ethic that enables them to refine their character and transcend the difficulties of life. In "The Dance at the Phoenix", jenny attains happiness in marriage through faithfulness and loving-kindness. The teacher of "In a Eweleaze near Weatherbury" transcends her old age and celebrates her memories of youth, beauty, and love. Another assertive female character appears in the "The Milkmaid", where the woman asserts her feminine power though a delicate and harmonious relationship with nature. Hardy presents strong women who defy traditions in "Her Late Husband" and "The Elopement". Both women achieve self-realisation through being true to themselves and rejecting the customs imposed by society. Unlike the previous poems, "Old Furniture" and "During Wind and Rain" do not present a specific woman; however, the concept of womanhood is central to the poems' notion of domestic happiness and the perpetuation of life. Woman as the source of life is also the topic of "In Times of 'The Breaking of Nations"', where a young woman stands for fecundity against the destruction of humanity in wars. In "Last Look round St Martin's Fair", "Expectation and Experience", and "We Field-Women"; Hardy presents stubborn women, who exert their will against a cruel and indifferent nature. Finally, Hardy's poetry 
presents lofty women, of free spirits and heroic temperaments. Their subjective way of life restores their honour through sincerity, competency and reverence.

\section{References}

Bayley, J. (1978). An essay on Hardy. Cambridge: Cambridge UP. https://doi.org/10.1017/ccol9780521660105.002

Bjork, L. A. (Ed.). (1985). The literary notes of Thomas Hardy. London: Macmillan and Co. Ltd., Vols I and II. https://doi.org/10.1007/978-1-349-06652-0

Cox, R. G. (Ed.). (1970). Thomas Hardy: The critical heritage. London: Routledge and Kegan Paul. https://doi.org//10.4324/9780203198957

Gibson, J. (Ed.). (1999). Thomas Hardy: Interviews and recollections. Houndmills: Macmillan.

Gibson, J., \& Johnson, T. (Eds.). (1979). Thomas Hardy: Poems: A casebook. London: Macmillan.

Gunn, T. (1979). “The influence of ballad-forms”. In Gibson (Ed.), Poems: A Casebook (pp. 217-232). London: Macmillan.

Hardy, T. (1983). The complete poems of Thomas Hardy. Edited by James Gibson. London: Macmillan.

Harvey, G. (2003). The complete critical guide to Thomas Hardy. London: Routledge.

Jaspers, K. (1951). Man in the modern Age. Trans. Eden and Cidar Paul. London: Routledge and Kegan Pul.

Lall, R. (2006). Thomas Hardy: Selected poems. New Delhi: Rama Brothers.

Maynard, K. K. (1991).Thomas Hardy's tragic poetry: The lyrics and the Dynasts. Iowa: Iowa UP. https://doi.org/10.2307/3735158

Mill, J. S. (1970). The subjection of women. Cambridge: MIT Press. https://doi.org/10.1093/hepl/9780198708926.003.0023

Miller, J. H. (1970). Thomas Hardy: Distance and desire. London: Oxford UP. https://doi.org/10.2307/40125133

Millgate, M. (1985). Thomas Hardy: A biography. Oxford: Oxford UP.

Patil, M. (1999). Thomas Hardy's poetry and existentialism. New Delhi: Atlantic Publishers and Distributors.

Pinion, F. B. (1977). Thomas Hardy: Art and thought. London: Macmillan. https://doi.org/10.1007/978-1-349-15765-5_3

Sartre, J. P. (1955). Existentialism. Trans. Bernard Frenchtman. London: Rider and Co., Hutchinson House. https://doi.org/10.2307/40087501

Stewart, J. I. M. (1971). Thomas Hardy: A critical biography. London: Longman.

Stumpf, S. E., \& Fieser, J. (2008). Socrates to Sartre and beyond: A History of Philosophy. New York: McGraw-Hill.

Williams, M. (1976). A preface to Hardy. New York: Longman.

\section{Copyrights}

Copyright for this article is retained by the author, with first publication rights granted to the journal.

This is an open-access article distributed under the terms and conditions of the Creative Commons Attribution license (http://creativecommons.org/licenses/by/4.0/). 